\title{
ARENITOS FLÚVIO-EÓLICOS DA PORÇÃO SUPERIOR DA FORMAÇÃO PIRAMBÓIA NO CENTRO-LESTE PAULISTA
}

\author{
MARIA RITA CAETANO-CHANG ${ }^{1} \&$ FU TAI WU ${ }^{1}$
}

\begin{abstract}
Keywords: fluvial-aeolian sandstones, fluvial-aeolian deposition, Triassic of Paraná Basin, Pirambóia Formation.
\end{abstract}
\begin{abstract}
Resumo Corpos de arenitos grossos e conglomeráticos, com formas e espessuras variadas, foram descritos, entre duas e três décadas atrás, como depósitos de origem fluvial, e posicionados próximo à base da Formação Botucatu. Estes arenitos, mais recentemente considerados como pertencentes à porção superior da Formação Pirambóia, são aqui caracterizados quanto à composição faciológica, com base na descrição de excelentes afloramentos nas proximidades de Itirapina, Descalvado e São Pedro, na região centro-leste paulista. A descrição dos perfis sedimentológicos mostra uma sucessão de arenitos geralmente mal selecionados, com granulometria variando de muito fina a muito grossa, com níveis conglomeráticos, exibindo estratificações cruzadas acanaladas, geralmente de médio porte. Tais arenitos foram também analisados por meio de microscopia ótica, tendo sido classificados como quartzarenitos, dominantemente. As relações laterais e verticais destes depósitos revelam interessante interação flúvio-eólica, restrita à porção superior da Formação Pirambóia na área. São aqui formalmente denominados Arenitos Itirapina, constituindo depósitos resultantes do estabelecimento de leques aluviais em áreas próximas da borda leste da bacia, ao final da sedimentação Pirambóia. Neste contexto, depósitos fluviais de canais entrelaçados são continuamente retrabalhados pelo vento, que interpõe depósitos eólicos de dunas, interdunas e lençóis de areia aos fluviais.
\end{abstract}

Palavras-chaves: arenitos flúvio-eólicos, deposição flúvio-eólica, Triássico da Bacia do Paraná, Formação Pirambóia.

\begin{abstract}
FLUVIAL-AEOLIAN SANSTONES FROM THE UPPER PORTION OF PIRAMBOIA FORMATION IN THE CENTRAL-EASTERN REGION OF SÃO PAULO STATE, BRAZIL Coarse and conglomeratic fluvial sandstones with varied thicknesses and geometries have been described in the literature and positioned at the lower portion of Botucatu Formation; more recently they were repositioned at the upper portion of Pirambóia Formation. These sandstones are here characterized with respect to their facies composition based on the description of excellent outcrops located in the vicinities of the cities of Itirapina, Descalvado and São Pedro, in the central-eastern portion of São Paulo State. Sedimentological log descriptions show a succession of very fine to coarse, poorly sorted sandstones, including conglomeratic beds, commonly exhibiting medium-scale trough-cross-stratifications. These sandstones have also been examined under optical microscopy and classified mainly as quartzarenites. The vertical and lateral relationships of these deposits revealed interesting fluvial-aeolian interaction, restricted to the upper portion of the Pirambóia Formation in the area. Itirapina Sandstones is the formal denomination for these sandstones deposited in alluvial mid-fans that were settled near the border of the basin, during the final episodes of Pirambóia sedimentation. In this context, braided fluvial deposits were continuously reworked by wind, which had intermingled aeolian deposits of dunes, interdunes and sand sheets to fluvial deposits.
\end{abstract}

INTRODUÇÃO Os Arenitos Itirapina foram primeiramente assim denominados, ainda que informalmente, por CaetanoChang (1997).

Arenitos grossos texturalmente imaturos e conglomeráticos, incomuns na coluna sedimentar da Formação Pirambóia, são mencionados por diversos autores (Bósio 1973, Soares 1973, Caetano-Chang \& Wu 1992, 1993, 1995; Assine \& Soares 1995, Caetano-Chang 1997) e em relatórios de levantamentos de campo não publicados, geralmente posicionados no topo da unidade.

Bósio (1973) identificou depósitos conglomeráticos no topo da Fácies Pirambóia, na região de São Pedro (SP).

Soares (1973), em abrangente estudo que definiu a Formação Pirambóia no Estado de São Paulo, acusou a presença de arenitos conglomeráticos com até uma dezena de metros de espessura, localmente, na base da Formação Botucatu. Descreveu-os como arenitos grossos conglomeráticos, friáveis e argilosos, com seixos de quartzo e quartzito, de tamanho variável, arredondados a angulares, alguns ventifactos, exibindo estratificações cruzadas de pequeno a médio portes. Segundo o autor, constituiriam depósitos de fluxos torrenciais, devido a correntes temporárias em ambiente desértico.

Para Assine \& Soares (1995), a presença mais significativa de arenitos conglomeráticos ocorre na metade superior da Formação Pirambóia, como conseqüência de progradação de sistemas fluviais de leste para oeste, evidenciando soerguimentos de áreas fontes a leste.

Caetano-Chang \& Wu $(1992,1993,1995)$ mencionam arenitos grossos e conglomeráticos, posicionados na porção superior da Formação Pirambóia, na região de São Pedro, Itirapina e Descalvado (SP), relacionando-os ao final da sedimentação Pirambóia na área, com alterações substanciais no suprimento detrítico à bacia.

Em continuidade a esses trabalhos e ao de Caetano-Chang (1997), esses arenitos são aqui detalhados quanto à sua faciologia e composições mineralógica e textural, com vistas à interpretação de sua gênese e caracterização estratigráfica, na região centro-leste paulista. A área escolhida (Fig.1) integra estudos anteriormente desenvolvidos pelos autores na região, onde foram verificadas espessas ocorrências desses arenitos conglomeráticos.

\section{MÉTODOS DE ESTUdO}

Dados de campo As melhores seções aflorantes na área de estudo estão localizadas nas regiões de Descalvado, Itirapina e São Pedro (Fig. 1). O levantamento dos afloramentos e seções foi realizado de maneira sistemática, através da descrição sedimentológica detalhada das diferentes litofácies formadoras, atendo-se principalmente às características texturais, mineralógicas, de estruturas sedimentares primárias e deformacionais, de forma e de espessura dos corpos rochosos e suas relações de 


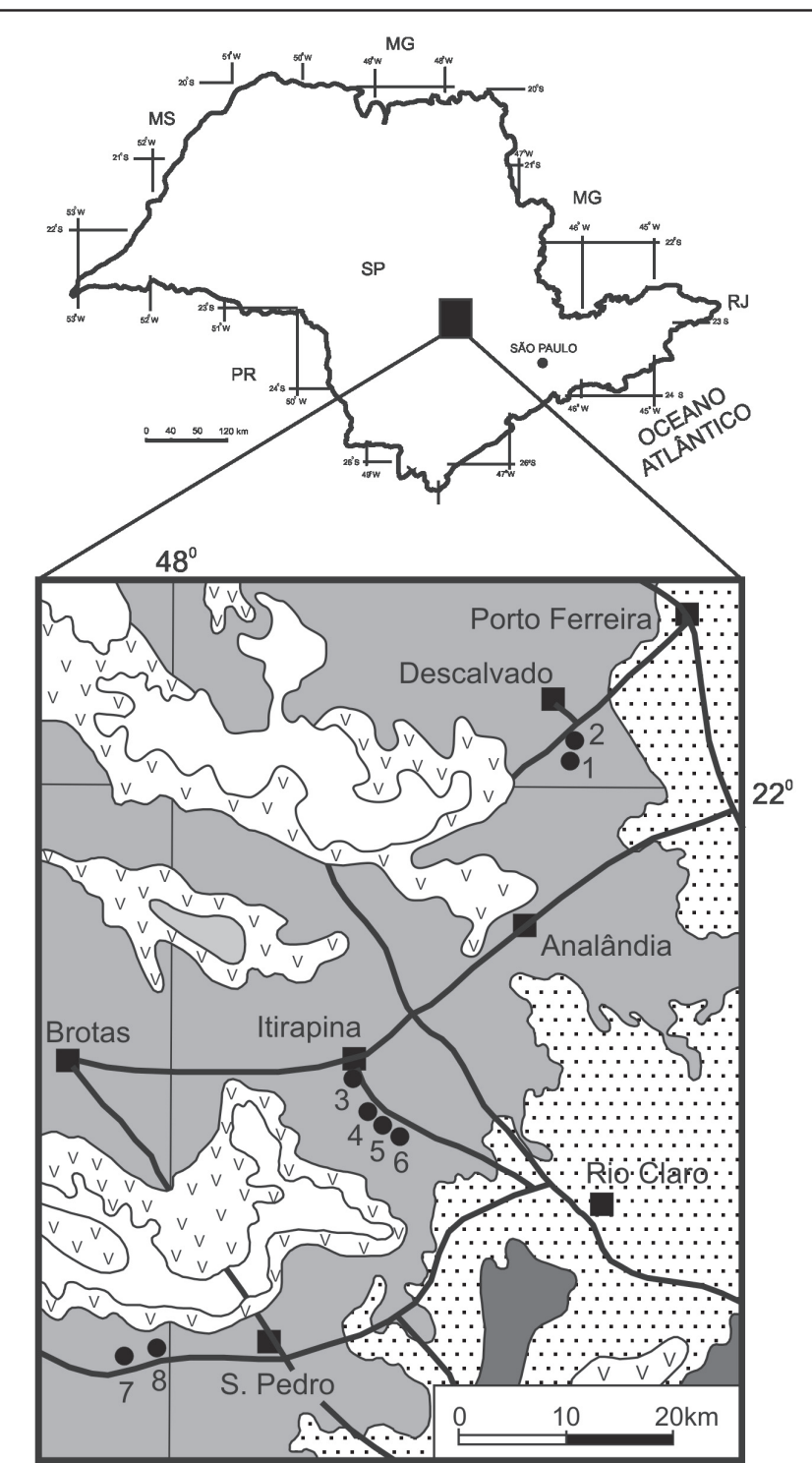

LEGENDA
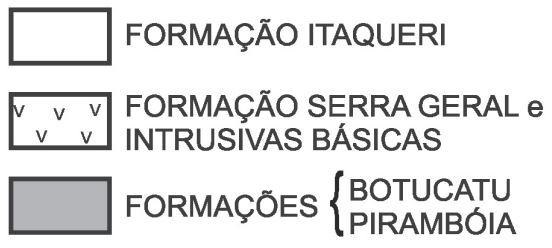

$\because \cdots$ GRUPO PASSA DOIS

$\square$ GRUPO TUBARÃO

\section{- SEÇÕES ESTUDADAS}

Figura 1. Mapa geológico simplificado da área de estudo, mostrando a localização das seções estudadas

contato. Durante os trabalhos de campo, foram utilizadas bases topográficas do IBGE, escala 1:50 000, para o adequado posicionamento dos afloramentos descritos.

Devido ao intenso intemperismo atuante sob as condições climáticas reinantes na área, alguns cuidados mínimos foram necessários durante a amostragem das rochas aflorantes. Assim, as porções superficiais da rocha, intensamente lixiviadas por águas de chuva e/ou modificadas por bioturbação atual, foram descartadas. No entanto, todo material coletado apresenta algum grau de telodiagênese.

Foram coletadas amostras pontuais, em seções descritas na área de estudo, cujas localizações estão representadas na figura 1; 24 amostras foram submetidas às análises granulométrica, de textura superficial e petrográfica. As amostras coletadas na área estudada compreendem principalmente arenitos e arenitos levemente lamíticos e conglomeráticos.

Análises de laboratório As amostras foram manipuladas pelo método convencional de análise granulométrica, via úmida, de sorte que a fração lama (silte + argila) foi retirada durante lavagem em peneira com abertura de malha $0,062 \mathrm{~mm}$; os intervalos de classe granulométrica utilizados foram de $1 / 2 \varnothing$.

O material resultante desta análise serviu à classificação granulométrica dos arenitos e à análise de textura superficial dos grãos à lupa binocular. Neste caso, utilizou-se a fração areia média, retirada da peneira de abertura $0,25 \mathrm{~mm}$, conforme sugestão de Folk (1974).

Com relação às lâminas delgadas, devido à friabilidade das amostras coletadas, estas tiveram que ser impregnadas com resina endurecedora, anteriormente à confecção das lâminas, seguindo método modificado de Cesero et al. (1989).

No estudo petrográfico, foram identificados e contados 100 grãos por lâmina delgada, tendo sido verificadas as características da matriz e do cimento. Em seguida, foram medidos o tamanho médio dos grãos e os valores correspondentes ao arredondamento, seguido de cálculo do grau de seleção, da maturidade textural e do índice de maturidade mineralógica.

ANÁLISE DE FÁCIES Os sedimentos da porção superior da Formação Pirambóia, na área estudada, são caracterizados por corpos de arenitos grossos e conglomeráticos, de origem fluvial, sempre intercalados verticalmente ou associados lateralmente a arenitos finos a médios, de origem eólica.

Esses depósitos exibem espessura variável, desde poucos metros mais comumente, até cerca de $45 \mathrm{~m}$ na área estudada. Excelentes exposições são encontradas ao longo da ferrovia FEPASA que liga as cidades de Rio Claro e Itirapina, mais próximo desta última; na região de Descalvado, em frentes de lavra da Mineração Jundu; e na Rodovia SP 191, próximo a São Pedro.

A descrição desses pacotes rochosos revela uma intrincada interação flúvio-eólica, em que depósitos fluviais, dominantes, são continuamente retrabalhados pelo vento, intercalando freqüentes depósitos eólicos, cujo registro revela um complexo processo de retrabalhamento.

As figuras 2A e B ilustram os perfis sedimentológicos (Seções 3 e 1, respectivamente; localização na Fig. 1) dos Arenitos Itirapina em Itirapina e Descalvado, revelando, em ambas, a dominância de depósitos fluviais grossos, intercalados subordinadamente por depósitos eólicos de dunas, interdunas e lençóis de areia

Nas proximidades de Itirapina, onde ocorre a maior espessura dos depósitos aqui estudados (45m), a descrição detalhada da seção completa foi dificultada pelo acesso aos paredões íngremes laterais à ferrovia e por constituírem cortes antigos, já muito ravinados e com vegetação superimposta. Desta sorte, optou-se aqui pela apresentação minuciosa do perfil sedimentológico de duas frentes de lavra da Mineração Jundu S.A. (Figura 2B), no sentido de melhor caracterizar a composição faciológica deste pacote rochoso.

Nesta seção, à semelhança do que se observa em várias frentes de lavra da mineração, o contato entre o pacote eólico 


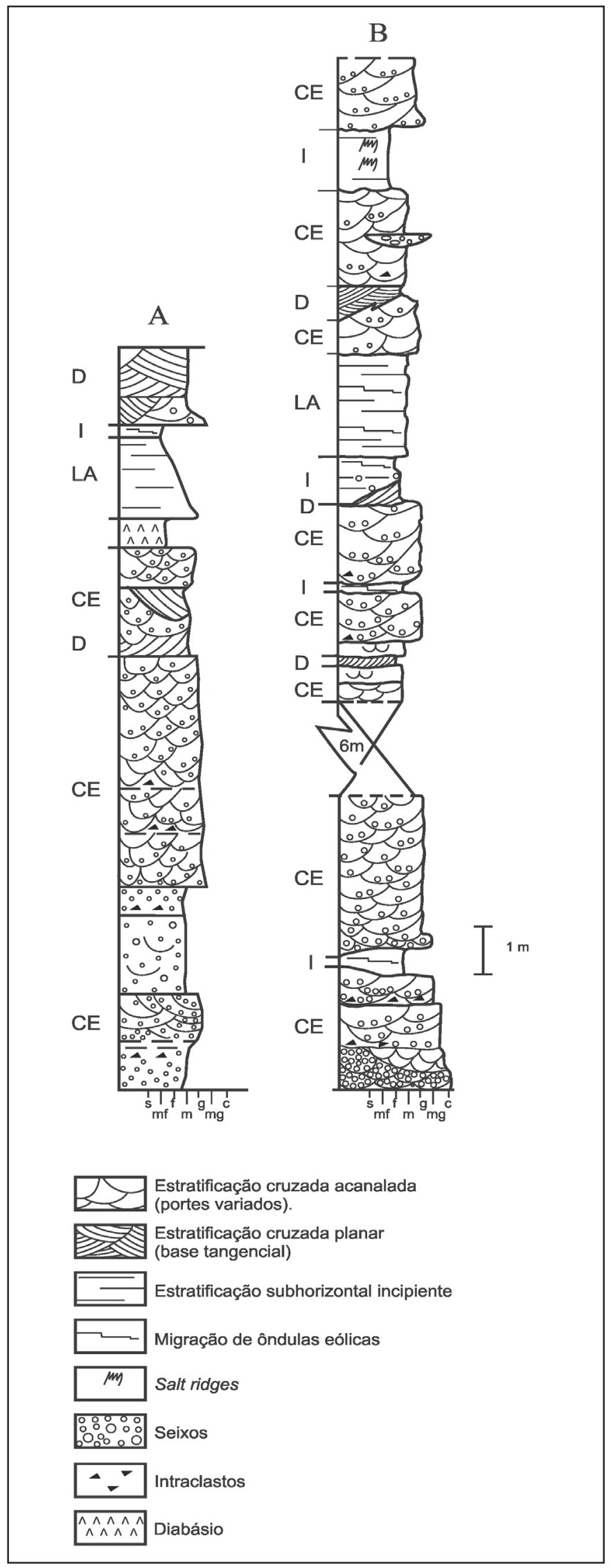

Figura 2. Perfis lito-faciológicos exibindo intercalações de fácies de barras de canais fluviais entrelaçados (CE) e fácies eólicas de dunas (D), interdunas (I) e lençóis de areia (LA), do topo da Formação Pirambóia. A. proximidades de Itirapina (Seção 3, Fig.1); B. frentes de lavra da Mineração Jundu (Seção 1, Fig.1), em Descalvado.

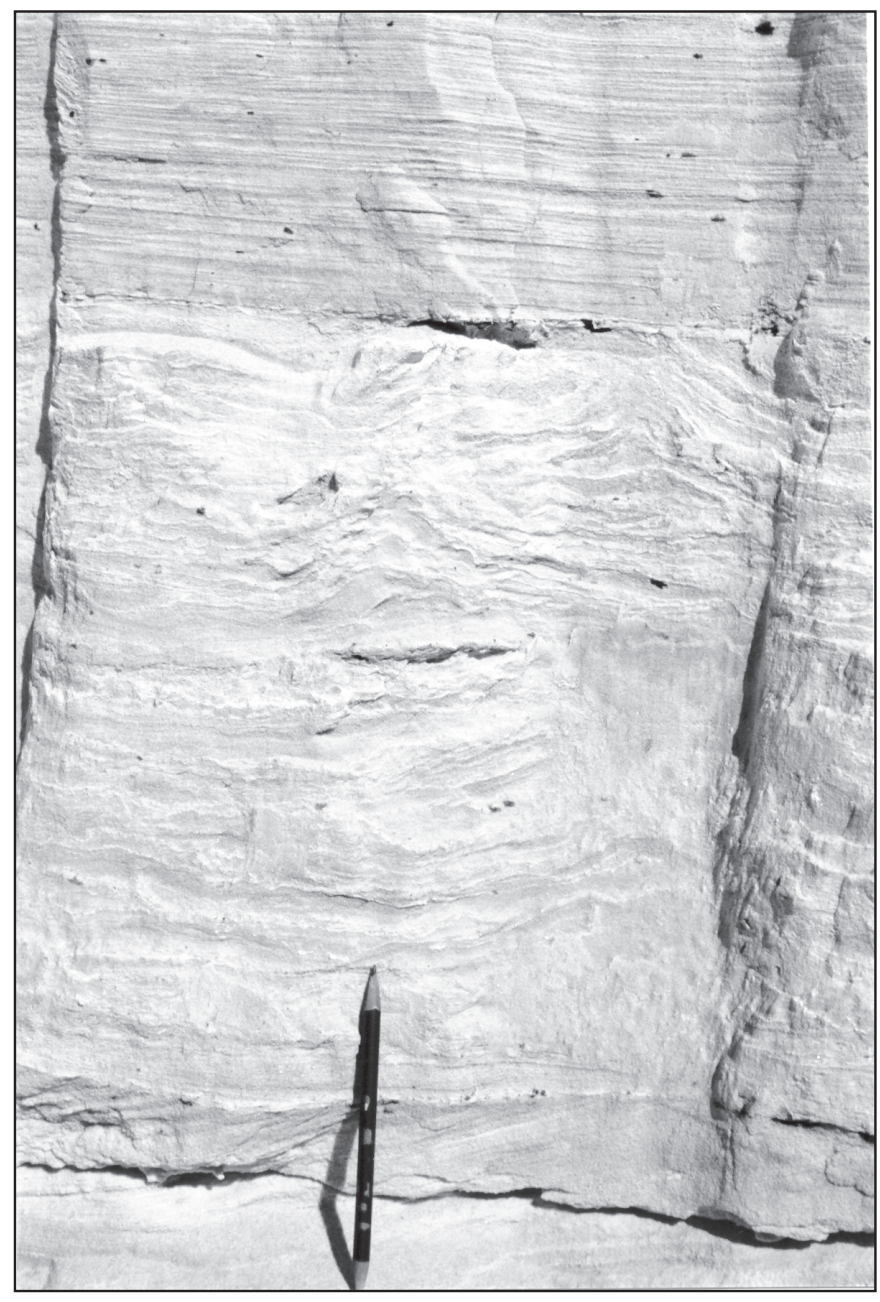

Figura 3. Arenitos finos da Formação Pirambóia, sotopostos aos Arenitos Itirapina, exibindo laminações irregulares (salt ridges) em fácies de sabkha-interdunas (Seção 1, Fig.1)

subjacente e o pacote essencialmente fluvial da porção superior da Formação Pirambóia é marcado por uma superfície erosiva aplainada, localmente irregular. Arenitos finos a médios, bem selecionados, com grãos variando de subangulares e subarredondados (menores) a bem arredondados (maiores), exibindo estratificações cruzadas de médio porte, tangenciais na base, com estrutura pin-strip, sotopõem-se ao pacote essencialmente fluvial do topo.Constituem depósitos de dunas eólicas, formados por fácies de foresets de avalanche e de base de foresets, com bimodalidade distinta. Intercalam lentes de fácies de interdunas (sabkha-interduna), compostas por arenitos dominantemente finos, subordinadamente médios, com laminações irregulares semelhantes a salt ridges (Fig.3).

Sobrepostos ocorrem arenitos conglomeráticos e conglomerados, cuja composição textural mostra freqüentes variações laterais e verticais, formando um conjunto de aproximadamente $6 \mathrm{~m}$ de espessura. Próximo à base, com espessura variando de $1 \mathrm{~m}$ a $0,2 \mathrm{~m}$, ocorrem conglomerados (Fig.4) compostos por seixos finos de quartzo e quartzitos, oblatos e esféricos, angulosos a arredondados, e intraclastos de arenitos finos e lamitos. Exibem incipiente estratificação cruzada, com seixos em parte arranjados segundo a estrutura, mas em geral desorganizados. Acima e lateralmente, ocorrem arenitos micáceos, finos a grossos, conglomeráticos, com seixos semelhantes aos anteriormente descritos, compondo uma sucessão em fining upward. Mostram estratificações cruzadas acanaladas de médio e grande portes, 


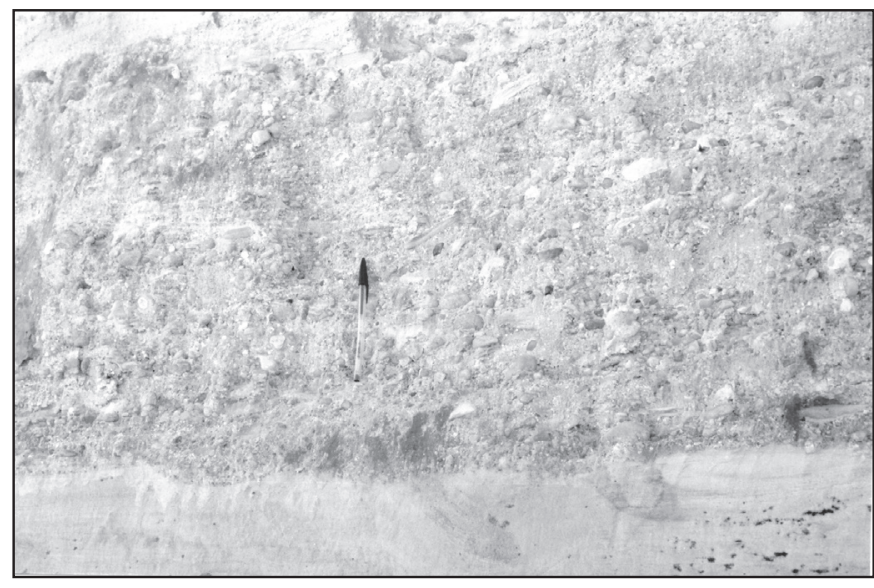

Figura 4. Conglomerados de fácies de barras de canais entrelaçados, exibindo seixos de quartzo e intraclastos de arenitos finos, acompanhando incipientes estratificações cruzadas.

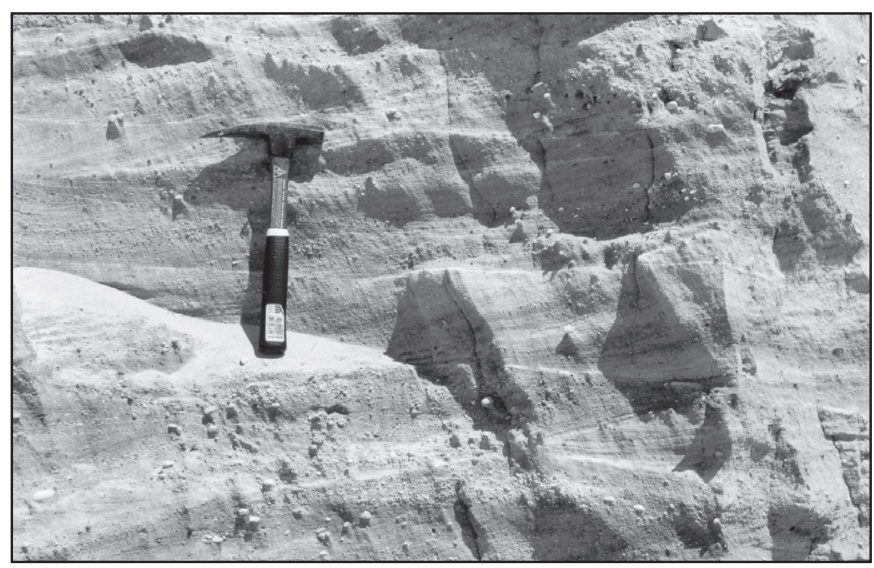

Figura 6. Arenitos conglomeráticos de fácies de barras de canais entrelaçados, exibindo estratificações cruzadas acanaladas.

com seixos acompanhando os estratos em suas porções inferiores; localmente intercalam-se arenitos com pequenos festoons. Esses depósitos são cortados em vários níveis por superfícies erosivas (duas principais), que constituem a expressão de paradas na sedimentação e erosão dos depósitos fluviais; localmente, estas superfícies apresentam intraclastos argilosos decimétricos (Fig.5). Acima ocorre corpo lenticular de arenitos eólicos finos a médios e subordinadamente médios a grossos, dispostos subhorizontalmente em lâminas bimodais; com espessura máxima de $1 \mathrm{~m}$, adelgaça-se rapidamente na lateral, cortado por canais fluviais preenchidos por arenitos conglomeráticos, com cruzadas acanaladas de pequeno e médio portes. São arenitos dominantemente médios a grossos, ligeiramente conglomeráticos (Fig.6), com seixos finos a médios, angulosos e arredondados, alguns ventifactos, de constituição essencialmente quartzosa (quartzo e quartzitos).

Alguns metros acima, ocorrem arenitos muito finos a grossos, mal selecionados e muito friáveis, com estratificações cruzadas acanaladas de pequeno porte; constituem arenitos de barras fluviais e sua espessura média é de cerca de $50 \mathrm{~cm}$. Sobrepostos, em contato erosivo, encontram-se arenitos muito finos a grossos, mal selecionados, com estratificações cruzadas acanaladas incipientes, silto-argilosos e micáceos. Constituem depósitos fluviais internamente cortados por superfícies erosivas,

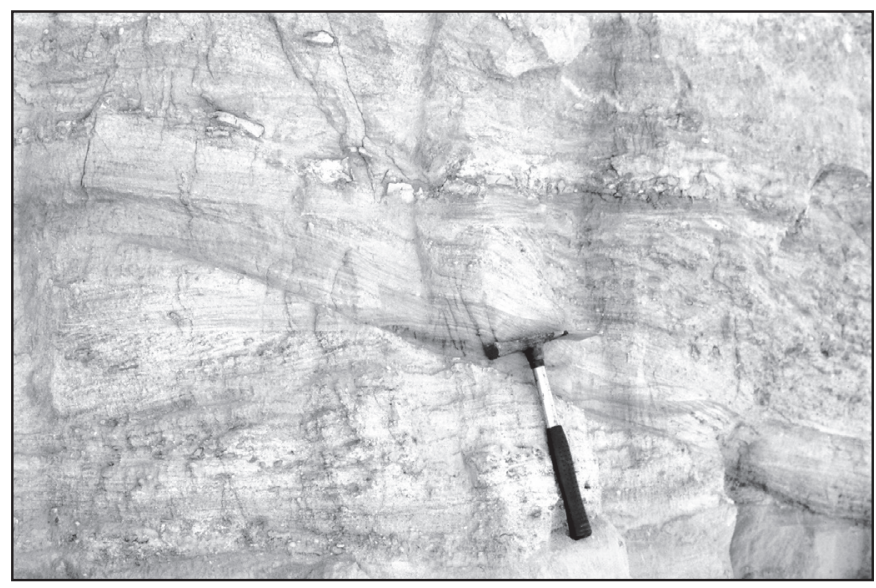

Figura 5. Detalhe de arenitos médios a grossos, de barras de canais entrelaçados, exibindo intraclastos de lamitos.

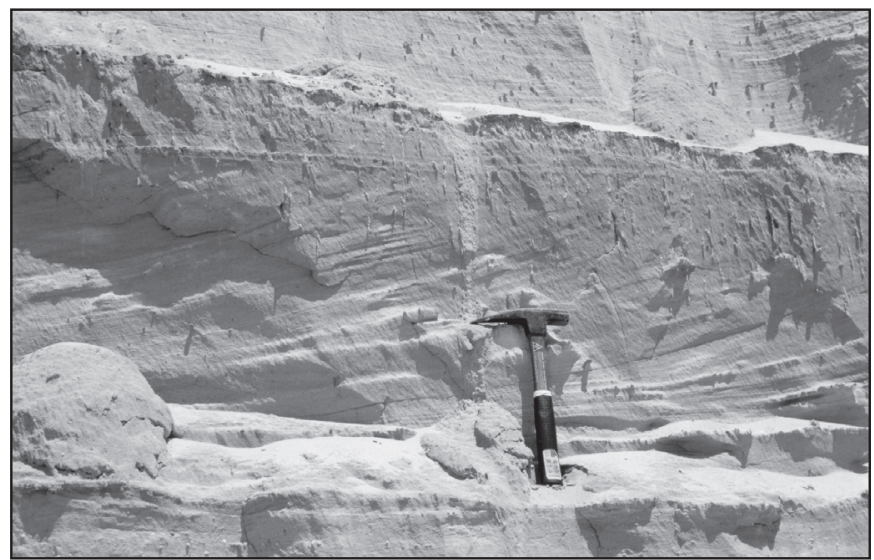

Figura 7. Arenitos de fácies de dunas eólicas exibindo estratificações cruzadas; acima, arenitos de fácies de lençóis de areia, sub-horizontais.

que separam delgado corpo de arenitos eólicos, finos a médios, bimodais, subarredondados a arredondados, com estratificação cruzada, cuja espessura máxima é de $20 \mathrm{~cm}$, desaparecendo lateralmente. A espessura total desses arenitos (fluvial + eólico) é de pouco mais de $1 \mathrm{~m}$. Acima, em contato erosivo, ocorrem arenitos finos a muito grossos, mal selecionados, conglomeráticos a levemente conglomeráticos, com seixos finos e grânulos de quartzo e quartzitos orientados segundo a estratificação ou acumulados na base dos foresets, além de intraclastos de lamitos; exibem estratificação cruzada acanalada de pequeno a médio portes. Interpõe-se a este conjunto, delgada (centimétrica, passando lateralmente a decimétrica) camada de arenitos eólicos, com incipiente estratificação sub-horizontal ditada pela migração de ôndulas eólicas, que passam lateralmente a cruzadas de pequeno porte, tangenciais na base, formadas pela migração de dunas eólicas. Os contatos entre os diversos corpos desses arenitos são erosivos; a espessura média deste pacote fluvial é de cerca de $3 \mathrm{~m}$.

Arenitos eólicos de interdunas úmidas sobrepõem-se, em contato erosivo, exibindo estratificação sub-horizontal incipiente e superfícies irregulares internas de deflação eólica, contendo grânulos de quartzo e quartzito; localmente, apresentam feições que se assemelham a salt ridges. São em geral arenitos finos, subordinadamente médios, com bimodalidade marcada pela migração de 


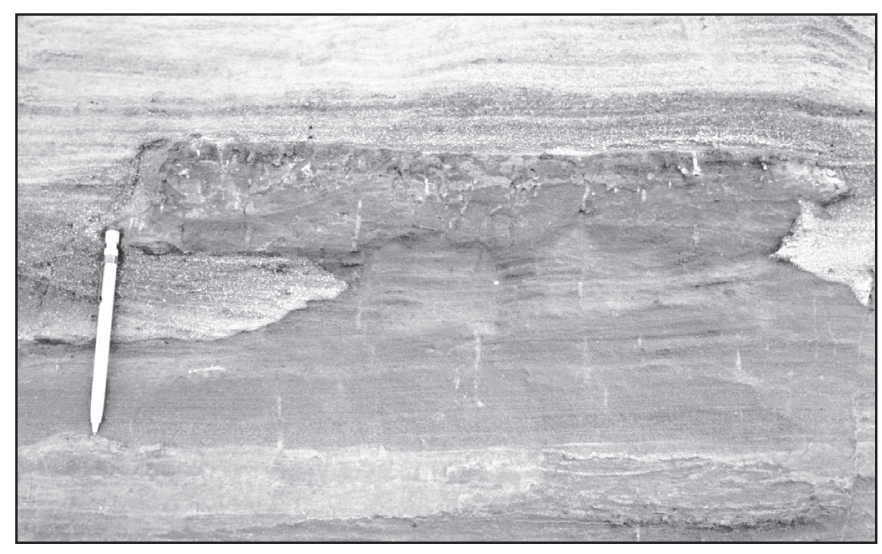

Figura 8. Detalhe do contato entre arenitos eólicos de fácies de interdunas (abaixo) e de lençóis de areia, mostrando vestígio de paleossolo.

ôndulas eólicas; lateralmente passam a depósitos de dunas, com foresets de pequeno a médio portes (Fig.7). A espessura máxima desses depósitos de interdunas é de aproximadamente 1m, adelgaçando-se lateralmente pela erosão irregular dos arenitos sobrepostos. O contato superior desses arenitos eólicos inclui vestígio de paleossolo (Fig.8). Sobrepostos, arenitos também eólicos, texturalmente mais grossos, constituem lençol de areia (Fig.8) que recobriu extensivamente os depósitos fluviais e eólicos subjacentes. São arenitos finos a grossos, dominantemente grossos a médios, bimodais, exibindo estratificação sub-horizontal a baixo ângulo, formada pela migração de ôndulas eólicas. A espessura máxima medida é $2,5 \mathrm{~m}$, sendo variável lateralmente.

Sobrepostos, em contato erosivo, arenitos de barras fluviais, finos a grossos, mal selecionados, levemente conglomeráticos, com seixos de quartzo e quartzitos, muitos dos quais mostrando formas aproximadas de ventifactos, exibem cruzadas acanaladas de médio até grande porte (Fig.9).

Apresentam geometria lenticular, com espessura máxima de $1,5 \mathrm{~m}$, desaparecendo lateralmente em poucos metros e intercalando arenitos eólicos com até $1 \mathrm{~m}$ de espessura. O corpo sobreposto é também formado por arenitos fluviais médios a grossos, subordinadamente finos, subarredondados, mal selecionados, exibindo localmente muitos intraclastos argilosos em foresets de cruzadas acanaladas de pequeno e médio portes; intraclastos de arenitos, centimétricos a decimétricos, ocorrem no fundo de canais. Este corpo, cuja espessura varia de 1 a $3 \mathrm{~m}$, é formado pelo amalgamento de corpos menores, de geometria acanalada, de depósitos de canal fluvial.

Acima, ocorrem arenitos sílticos com estruturas mal definidas, irregulares, que se assemelham a salt ridges; lateralmente exibem cruzadas de pequeno porte com bimodalidade. Constituem provável registro de interduna úmida ou sabkha, com cerca de $1,5 \mathrm{~m}$ de espessura. O corpo superior sobrepõe-se a superfície de erosão bem demarcada; os arenitos são levemente conglomeráticos, com seixos de quartzo e quartzitos esparsos, que acompanham a estratificação cruzada acanalada de médio porte.

Na região de São Pedro, os depósitos da porção superior da Formação Pirambóia apresentam significativo aumento textural, diferenciando-se significativamente dos arenitos sotopostos.

Quanto à faciologia, predominam fácies eólicas, em geral de textura média a grossa (Fig.10), interrompidas localmente por fácies fluviais de arenitos conglomeráticos, comparáveis aos descritos em Itirapina e Descalvado.

A figura 11 (Seção 8; localização na Fig.1) constitui um bom exemplo destas fácies, exibindo intercalações de dunas e lençóis de areia amalgamados. Estes últimos mostram superfícies ero-

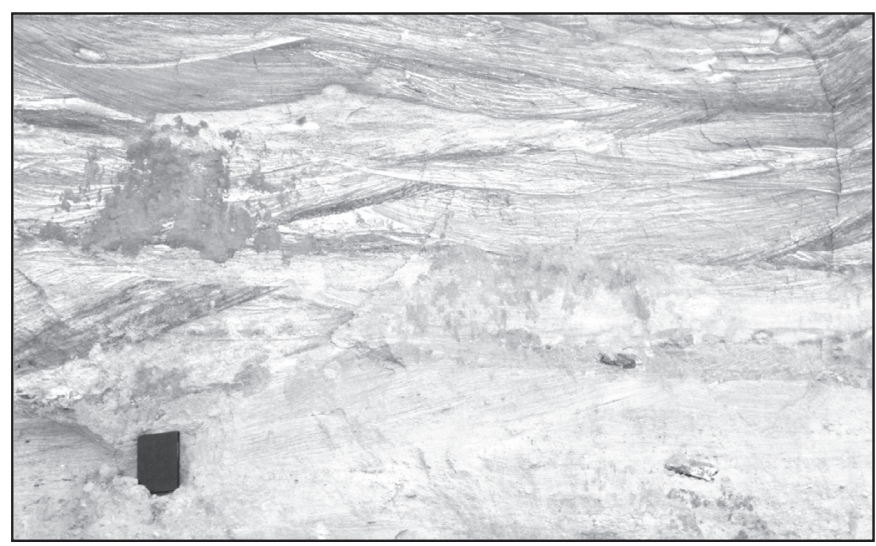

Figura 9. Estratificações cruzadas acanaladas em arenitos de fácies de barras de canais entrelaçados.

sivas realçadas por: delgados níveis de seixos finos e grânulos, que marcam os contatos entre os corpos litológicos; variações texturais entre os corpos arenosos (médios a grossos e finos a médios); e variações suaves de inclinação, exibindo estratificações sub-horizontais evidenciadas por lâminas de areia média a grossa de migração de ôndulas eólicas . Tais características são indicativas de mudanças no suprimento detrítico à bacia $\mathrm{e}$ no regime de fluxo dos ventos. Próximo à base do perfil, ocorre intercalação métrica de arenitos médios e muito grossos, com grânulos e seixos finos, mal selecionados, exibindo estratificações cruzadas acanaladas de pequeno porte, constituindo fácies de canal fluvial.

Em resumo, as seções estudadas exibem fácies de barras de canais fluviais entrelaçados (CE), fácies eólicas de foresets de dunas (D), de interdunas (I) e de lençóis de areia (LA) (Fig.2 e 11), em intrincada associação, reflexo da competição entre os sistemas fluvial e eólico no ambiente deposicional.

Da análise granulométrica de arenitos das fácies acima descritas, depreende-se que as modas mais comuns são: areia fina a média nos arenitos eólicos e areia média a grossa nos arenitos fluviais, sendo ambos regular a mal selecionados. Tal característica deve-se à mistura das frações granulométricas durante a análise, motivo pelo qual a análise petrográfica torna-se deveras importante para o entendimento da organização textural nestas rochas.

Outra característica interessante, verificada pela análise granulométrica, é que a fração menor que $0.062 \mathrm{~mm}$ ocorre em porcentagens relativamente elevadas, tanto nos arenitos fluviais quanto nos eólicos, freqüentemente em torno de $5 \%$, chegando a $15 \%$. No entanto, ao contrário do assinalado em trabalhos mais antigos (Bósio 1973, Soares 1973, 1975), o silte grosso - e não a argila — constitui a granulometria dominante nesta fração. Como já observado por Caetano-Chang \& Wu (1992, 1993), os siltes são oriundos geralmente de processos eólicos de queda de grãos, enquanto as argilas, em grande parte, resultam de infiltrações mecânicas.

A análise da textura superficial das amostras submetidas previamente à análise granulométrica revelou alta porcentagem $(>80 \%)$ de grãos foscos na maioria dos arenitos, eólicos ou fluviais.

Rumos de paleocorrentes, medidos em estratificações cruzadas de fácies fluviais, indicam sentido WNW para o fluxo fluvial.

ANÁLISE PETROGRÁFICA Para as análises textural e mineralógica ao microscópio ótico, foram separadas 24 amostras de fácies dos Arenitos Itirapina, escolhendo-se as porções menos seixosas para confecção das lâminas delgadas. 


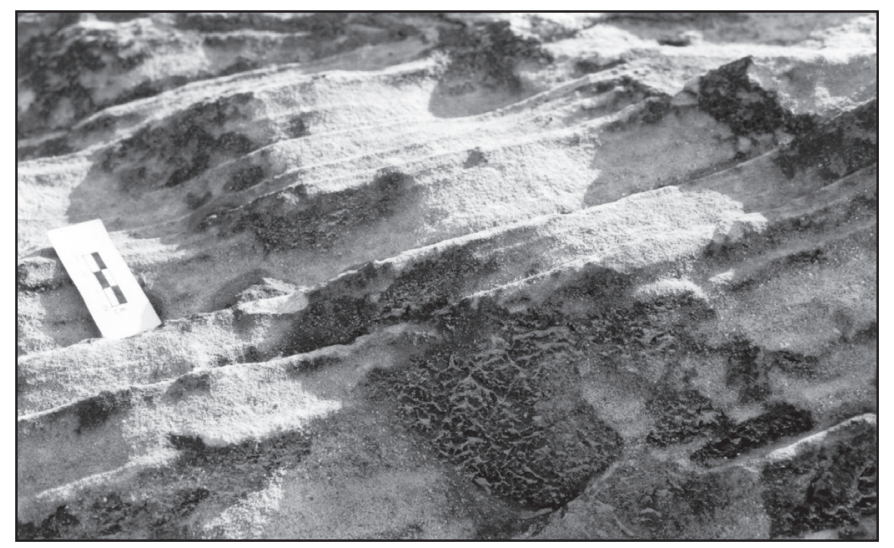

Figura 10. Fácies de foresets de dunas eólicas pertencentes aos Arenitos Itirapina, nas proximidades de São Pedro (Seção 7, Fig.1).

A tabela 1 traz a mineralogia destes arenitos, seu conteúdo em matriz e cimento, bem como tamanho médio, arredondamento, grau de seleção, maturidades textural e mineralógica dos grãos. Os principais componentes encontrados são quartzo, feldspato, fragmentos de rocha, além de cimento e matriz.

O quartzo é o componente mineralógico ultrapredominante (Vide Tabela 1 para Escala Nominativa de Abundância) destes arenitos, muitas vezes apresentando início de corrosão (Fig.12), superfícies côncavas ou serrilhadas, às vezes dissolução total; o crescimento secundário ao redor de um núcleo de quartzo detrítico é escasso, sendo comum a deposição de fina película de óxidos e/ou hidróxidos de ferro, que fazem parte do material cimentante. Foram identificadas duas variedades: quartzo monocristalino e quartzo policristalino, incluindo sílex.

O feldspato é constituinte acidental e abundante em algumas amostras; apresenta tamanho menor que o do quartzo e consiste geralmente de ortoclásio, mícroclínio e plagioclásios alcalinos, intemperizados parcialmente e alterados (Fig.13) a caulinita e/ou ilita.

Os fragmentos de rocha são constituintes traço nos arenitos estudados (muito abundante apenas em uma amostra); incluem fragmentos de filitos e lamitos (Fig.14).

Os grandes fragmentos ( $>20$ micra) de mica são principalmente de moscovita, concentrados em geral em arenitos finos a muito finos; são fragmentos angulosos, com formas alongadas, às vezes curvadas, em quantidade menor que $1 \%$ (traço).

O cimento consiste de óxido de ferro e argila autigênica, aderindo-se à superfície dos grãos ou preenchendo parcialmente os poros. Calcita e, em menor quantidade, pirita aparecem como manchas que cimentam localmente os grãos.

A matriz original é síltica e argilo-micácea; a matriz secundária é composta por argilas infiltradas (Fig.14), formando fina película que envolve os grãos ou preenchendo vazios.

Segundo a classificação de Folk (1974), os arenitos grossos e conglomeráticos do topo da Formação Pirambóia são principalmente quartzarenitos e raramente subarcóseos, sendo descrito um litarenito feldspático. Estas últimas exibem maturidade mineralógica entre 94 e 75\% (proporção de quartzo, sílex e quartzito, segundo Hubert 1962), sendo consideradas maturas a submaturas, enquanto os quartzarenitos são todos supermaturos (Tabela 1).

Os quartzarenitos e o subarcóseo de origem eólica são principalmente de granulometria muito fina a grossa, subarredondados a bem arredondados, contendo argila infiltrada, ferruginosos, com grau de seleção boa a regular e texturalmente submaturos a supermaturos (Tabela 1). A distribuição granulométrica destes

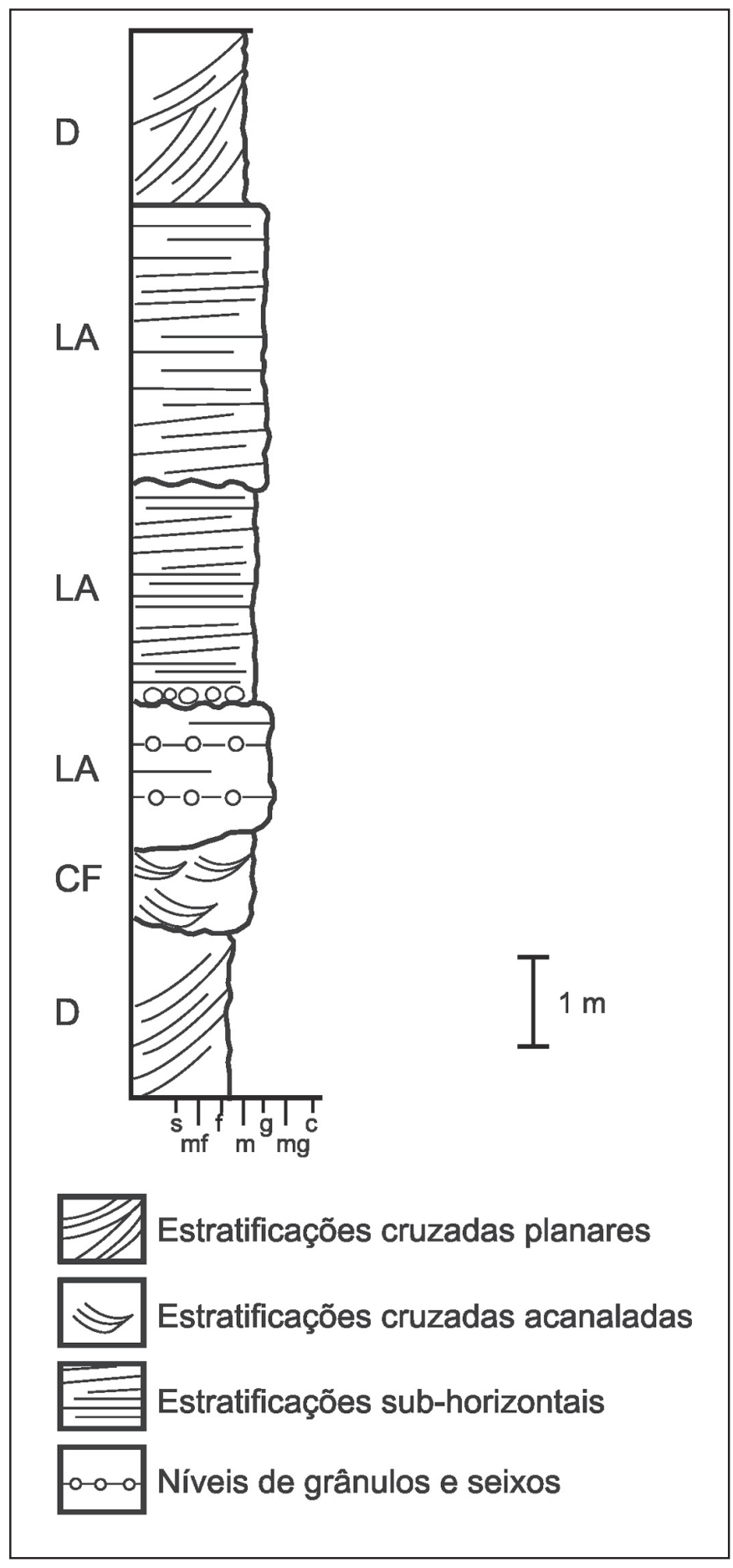

Figura 11. Perfil lito-faciológico ilustrando intercalações de fácies eólicas de dunas (D) e lençóis de areia (LA) e fácies de canais fluviais (CF), do topo da Formação Pirambóia, proximidades de São Pedro (Seção 8, Fig.1).

arenitos é comumente bimodal, com modas nas frações de areia média a grossa e muito fina a fina, que em geral se separam em lâminas distintas (Fig.15). Dessa forma, os arenitos, são classificados como regular a pobremente selecionados, mas cada fração em separado é bem selecionada. Nestes casos, o arenito pode ser chamado "bimodal maturo" ou "bimodal supermaturo" dependendo do arredondamento. Os arenitos médios a grossos são texturalmente submaturos (bimodal maturo a supermaturo) e os arenitos finos são maturos a supermaturos. Os grãos médios e grossos são por vezes orientados e sempre possuem arre- 
Tabela 1. Composição mineralógica e características texturais dos Arenitos Itirapina.

\begin{tabular}{|c|c|c|c|c|c|c|c|c|c|c|c|c|c|c|c|c|c|c|c|}
\hline \multirow{3}{*}{$\begin{array}{l}\text { AMOS- } \\
\text { TRAS }\end{array}$} & \multirow[t]{3}{*}{ FÁCIES } & \multirow{3}{*}{$\begin{array}{c}\text { TAMANHO } \\
\text { DOS } \\
\text { GRÃOS }\end{array}$} & \multirow[t]{3}{*}{ SELEÇÃO } & \multirow{3}{*}{$\begin{array}{l}\text { ARRE- } \\
\text { DONDA- } \\
\text { MENTO }\end{array}$} & \multirow{3}{*}{\begin{tabular}{|l|} 
MATURI- \\
DADE \\
TEXTURAL
\end{tabular}} & \multicolumn{9}{|c|}{ COMPOSIÇÃO MINERALÓGICA } & \multirow{2}{*}{\multicolumn{2}{|c|}{ MATRIZ }} & \multirow{3}{*}{$\begin{array}{c}\text { CIMEN- } \\
\text { TO }\end{array}$} & \multirow{3}{*}{$\begin{array}{l}\text { MAT. } \\
\text { MIN. }\end{array}$} & \multirow[t]{3}{*}{ LITOLOGIAS } \\
\hline & & & & & & \multicolumn{3}{|c|}{ QUARTZO } & \multicolumn{2}{|c|}{ FELDSPATO } & \multicolumn{3}{|c|}{ ROCHAS } & \multirow[t]{2}{*}{ MICA } & & & & & \\
\hline & & & & & & QM & QP & Sx & FK & PL & LM & LS & LV & & $\mathrm{O}$ & $\mathrm{S}$ & & & \\
\hline $1 \mathrm{~A}$ & $\mathrm{D}$ & g-mg,m-f & $r-b$ & sar-bar & mt-spm & 99 & 1 & - & - & - & - & - & - & - & st & - & - & 100 & Quartzarenito \\
\hline 1D & D & $m-g, f-m f$ & $r-b$ & sar-bar & mt-spm & 99 & 1 & - & - & - & - & - & - & - & st & - & - & 100 & Quartzarenito \\
\hline $1 \mathrm{EI}$ & D & $\mathrm{m}-\mathrm{f}(\mathrm{g}, \mathrm{mf})$ & $r-b$ & sa-bar & mt-spm & 100 & $\mathrm{~T}$ & - & $\mathrm{T}$ & - & - & - & - & $\mathrm{T}$ & st & arg & $\mathrm{Fe}$ & 100 & Quartzarenito \\
\hline 1E2 & $\mathrm{CE}$ & $m-f, g-m$ & $\mathrm{r}$ & sa-ar & sm & 100 & $\mathrm{~T}$ & - & $\mathrm{T}$ & - & - & - & - & $\mathrm{T}$ & st,arg & arg & - & 100 & Quartzarenito \\
\hline $1 \mathrm{~F}$ & LA & $\mathrm{g}-\mathrm{m}(\mathrm{mg}, \mathrm{f})$ & $r-b$ & sar-bar & sm-spm & 99 & 1 & - & - & - & - & - & - & - & st & arg & - & 100 & Quartzarenito \\
\hline $1 \mathrm{H}$ & $\mathrm{CE}$ & $\mathrm{m}-\mathrm{g}, \mathrm{f}-\mathrm{m}$ & $r-b$ & sa-bar & sm-mt & 100 & $\mathrm{~T}$ & - & - & - & - & - & - & $\mathrm{T}$ & st,arg & arg & - & 100 & Quartzarenito \\
\hline $2 \mathrm{~A}^{1}$ & Df & $m-g, f-m f$ & $r-b$ & sa-bar & sm-mt & 100 & $\mathrm{~T}$ & - & - & - & - & - & - & - & st & - & - & 100 & Quartzarenito \\
\hline $2 \mathrm{~A}^{2^{*}}$ & $\mathrm{CE}$ & $\mathrm{f}-\mathrm{gr}$ & $\mathrm{m}$ & sa-sar & $\mathrm{sm}$ & 88 & 12 & - & - & - & - & - & - & - & st,arg & arg & - & 100 & Quartzarenito \\
\hline $2 \mathrm{~A}^{3}$ & Df & $f-m(g, m f)$ & $\mathrm{r}$ & sa-bar & $\mathrm{sm}-\mathrm{mt}$ & 100 & - & - & - & - & - & - & - & - & st & $\arg$ & - & 100 & Quartzarenito \\
\hline $2 \mathrm{~B}^{2}$ & $\mathrm{CE}$ & $m f-f$ & $\mathrm{~b}$ & $\mathrm{a}$-sar & sm-im & 100 & - & - & - & - & - & - & - & A & st,arg & $\arg$ & $\mathrm{Fe}$ & 100 & Quartzarenito \\
\hline $2 \mathrm{~B}^{3}$ & $\mathrm{CE}$ & $m-g(f)$ & $r-b$ & sa-ar & $\mathrm{sm}-\mathrm{mt}$ & 100 & - & - & - & - & - & - & - & F & st,arg & arg & $\mathrm{Fe}$ & 100 & Quartzarenito \\
\hline $2 B^{4}$ & $\mathrm{CE}$ & $m f-f, f-m$ & $r-b$ & sa-bar & $\mathrm{sm}-\mathrm{mt}$ & 100 & - & - & - & - & - & - & - & $\mathrm{T}$ & st,arg & arg & $\mathrm{Fe}$ & 100 & Quartzarenito \\
\hline $2 \mathrm{~B}^{4^{*}}$ & $\mathrm{CE}$ & mf-gr & $m-r$ & sa-ar & $\mathrm{sm}$ & 90 & 10 & - & - & - & - & - & - & $\mathrm{T}$ & st,arg & arg & $\mathrm{Fe}$ & 100 & Quartzarenito \\
\hline $2 \mathrm{~B}^{5}$ & $\mathrm{CE}$ & $m-g, f-m f$ & $r-b$ & a-bar & sm-mt & 100 & $\mathrm{~T}$ & - & - & - & - & - & - & $\mathrm{T}$ & st & - & - & 100 & Quartzarenito \\
\hline $2 \mathrm{C}$ & $C E$ & $\mathrm{mf}-\mathrm{m}, \mathrm{m}-\mathrm{g}$ & $m-r$ & sa-bar & $\mathrm{sm}-\mathrm{mt}$ & 97 & 3 & - & - & - & - & - & - & $\mathrm{T}$ & st,arg & $\arg$ & $\mathrm{Fe}$ & 100 & Quartzarenito \\
\hline $2 C^{*}$ & $\mathrm{CE}$ & mf-gr & $\mathrm{m}$ & a-sar & $\mathrm{sm}$ & 70 & 30 & - & - & - & - & $\mathrm{T}$ & - & $\mathrm{T}$ & st arg & arg & $\mathrm{Fe}$ & 100 & Quartzarenito \\
\hline $3 \mathrm{~A}$ & $\mathrm{CE}$ & $\mathrm{m}-\mathrm{f}, \mathrm{g}-\mathrm{mg}$ & $\mathrm{r}$ & sar-bar & sm-mt & 99 & 1 & $\mathrm{~T}$ & $\mathrm{~T}$ & - & - & $\mathrm{T}$ & - & $\mathrm{T}$ & st,arg & arg & $\mathrm{Fe}$ & 100 & Quartzarenito \\
\hline 5 & $\mathrm{CE}$ & $\mathrm{mf}-\mathrm{m}, \mathrm{g}-\mathrm{mg}$ & $\mathrm{r}-\mathrm{m}$ & sa-bar & $\mathrm{sm}$ & 92 & 2 & $\mathrm{~T}$ & 6 & $\mathrm{~T}$ & - & - & - & $\mathrm{T}$ & st,arg & arg & $\mathrm{Fe}$ & 94 & Subarcóseo \\
\hline $6 \mathrm{~B}$ & $\mathrm{CE}$ & $\mathrm{mf}-\mathrm{m}, \mathrm{g}-\mathrm{mg}$ & $\mathrm{m}$ & a-bar & $\mathrm{im}$ & 72 & 2 & - & 12 & $\mathrm{~T}$ & 14 & - & - & MF & st,arg & $\arg$ & $\mathrm{Fe}$ & 75 & Litarenito Feldsp. \\
\hline $7 \mathrm{~A}$ & D & $\mathrm{m}-\mathrm{f}(\mathrm{g})$ & b & sar-bar & spm & 94 & $\mathrm{~T}$ & - & 6 & - & - & - & - & $\mathrm{T}$ & st & arg & $\mathrm{Fe}$ & 94 & Subarcóseo \\
\hline $8 \mathrm{~B}$ & $\mathrm{CE}$ & $\mathrm{m}-\mathrm{g}(\mathrm{f}, \mathrm{mg})$ & $\mathrm{r}$ & sa-bar & sm & 97 & 3 & - & - & - & - & - & - & $\mathrm{T}$ & st,arg & $\arg$ & $\mathrm{Fe}$ & 100 & Quartzarenito \\
\hline $8 \mathrm{C}$ & LA & $\mathrm{m}-\mathrm{g}, \mathrm{mf}-\mathrm{f}$ & $\mathrm{m}-\mathrm{r}$ & a-bar & $\mathrm{sm}$ & 98 & 2 & - & $\mathrm{T}$ & - & - & - & - & $\mathrm{T}$ & st & $\arg$ & $\mathrm{Fe}$ & 100 & Quartzarenito \\
\hline
\end{tabular}

Convenções: Fácies: $\mathrm{D}=$ duna; $\mathrm{Df}=$ porção basal de foreset de duna; l=interduna; La =lençol de areia; $\mathrm{CE}=$ canal entrelacado; Tamanho dos grãos : silte= st; areias: $\mathrm{mf}=$ muito fina; $\mathrm{f}=$ fina; $\mathrm{m}=$ média; $\mathrm{g}=$ grossa; $\mathrm{mg}=$ muito grossa; $\mathrm{gr}=$ grânulos; Seleçã $\mathrm{b}=\mathrm{boa}, \mathrm{r}=$ regular; $\mathrm{m}=$ má; Arredondamento; $\mathrm{a}=$ angular; as= subangular; sar = subarrendondado; ar = arredondado; bar= bem arredondado; Maturidade Textural: im= imaturo; sm= submaturo; $\mathrm{mt}=$ maturo; $\mathrm{spm}=$ supermaturo; Mineralogia: $\mathrm{QM}=\mathrm{quartzo}$ monocristalino; $\mathrm{QP}=$ quartzo policristalino; $\mathrm{SX}=$ sílex; Feldspatos: $\mathrm{FK}=$ feldspato potássico; $\mathrm{PL}=$ plagioclásio; Fragmentos de Rochas: $\mathrm{LM}=$ metamórficas; LS= sedimentares; LV= vulcânicas; Escala Nominativa de Abundância (modif. Wu 1981): Ultra-predominante (>40\%); Predominante (20 a $40 \%$ ); Muito Abundante (10 a 20\%); $\mathrm{A}=$ Abundante $(5-10 \%) ; \mathrm{F}=$ Freqüente (2-3\%); $\mathrm{MF}=$ Muito Freqüente (3-5\%); $\mathrm{E}=$ Escasso (1-2\%); $\mathrm{T}=$ Traço $(<1 \%) ;-$ = não encontrado; Matriz: $\mathrm{O}=$ original; $\mathrm{S}=$ secundária; arg= argila; st= silte; Cimento: $\mathrm{Fe}=$ óxido de ferro.

dondamento bimodal, ou seja, grãos arredondados e angulosos coexistem na mesma classe; os grãos maiores, angulosos, são encontrados nos arenitos de fácies de lençol de areia.

Os quartzarenitos, o litarenito feldspático e o subarcóseo de origem fluvial mostram, em geral, granulometria, seleção e arredondamento muito variáveis. São arenitos com grãos desde muito finos até muito grossos e grânulos, mal a bem selecionados, com dominância de seleção regular, arredondamento desde angular até bem arredondado, com dominância de subangular a arredondado, e maturidade textural variando de imaturo a maturo. É comum a ocorrência de inversão textural nesses arenitos, em que os grãos mais grossos (grânulos a areias grossas) são subangulosos e os grãos mais finos (areias médias a muito finas) são arredondados.

Em resumo, os minerais leves dos arenitos da porção superior da Formação Pirambóia são essencialmente quartzo e apenas traços de micas e fragmentos de rochas. O quartzo monocristalino é amplamente dominante, em geral ocorrendo em quantidades acima de $90 \%$; o quartzo policristalino, embora em geral ocorra em percentuais muito baixos, mostra ocorrência elevada em arenitos grossos ligeiramente conglomeráticos. Os Arenitos Itirapina são em geral mineralogicamente supermaturos e texturalmente submaturos a supermaturos.

AMBIENTE DEPOSICIONAL E POSICIONAMENTO ESTRATIGRÁFICO A interação flúvio-eólica em ambientes continentais, desérticos ou não, é largamente reconhecida tanto em registros geológicos antigos quanto em situações recentes.

Langford (1989) e Langford \& Chan (1989) desenvolveram modelos deposicionais com base no estudo de sedimentos resultantes de interações flúvio-eólicas. Segundo Caetano-Chang (1997), diversas feições descritas no modelo conceitual destes autores podem ser encontradas na Formação Pirambóia, desde sua base até a porção superior.

O caso específico dos Arenitos Itirapina, no entanto, refe- re-se a ambientes de leque aluvial de borda de deserto, mais especificamente de mid-fan, onde depósitos de barras de sistema fluvial entrelaçado são continuamente retrabalhados pelo vento, resultando em faciologia complexa de diferentes fácies eólicas e fácies de barras fluviais.

Esses depósitos fluviais, agrupados sob a designação de fácies de canais entrelaçados (CE), são formados pelo amalgamento de corpos arenosos de barras fluviais. Ainda que dominantes, estes depósitos competem no registro sedimentar com depósitos de um sistema eólico atuante na área que, embora em geral texturalmente mais grossos que no restante da unidade, podem ser classificados dentro das mesmas fácies eólicas de $\mathrm{Ca}$ etano-Chang (1997).

Considerando-se o conjunto desses depósitos na área de estudo, as fácies de canais entrelaçados podem ser descritas como formadas por corpos geralmente métricos de arenitos finos a grossos, mal selecionados, com porcentagem variável da fração cascalho, variando de levemente conglomeráticos $(\sim 5 \%$ de seixos) a conglomeráticos ( $\sim 20 \%$ de seixos $)$, dominantemente quartzosos, apresentando estratificações cruzadas acanaladas, em geral de médio porte. Níveis lamíticos são incomuns; intraclastos de argila podem ser abundantes.

Embora os afloramentos da porção superior da Formação Pirambóia sejam relativamente menos freqüentes que os de posições inferiores, é marcante a ocorrência de espessos pacotes de fácies fluviais de canais entrelaçados nesta porção. Em seções strike (perpendiculares ao mergulho deposicional), seu registro parece ser descontínuo. Tais características sugerem a ocorrência de leques aluviais em parte coalescentes, em parte isolados, associados a possíveis episódios de chuvas torrenciais e área-fonte soerguida.

As fácies eólicas, via de regra texturalmente mais grossas que as encontradas em porções inferiores da Formação Pirambóia, indicam a ocorrência de significante mudança no suprimento detrítico nesta posição estratigráfica. As características texturais dos arenitos da porção superior da Formação Piram- 


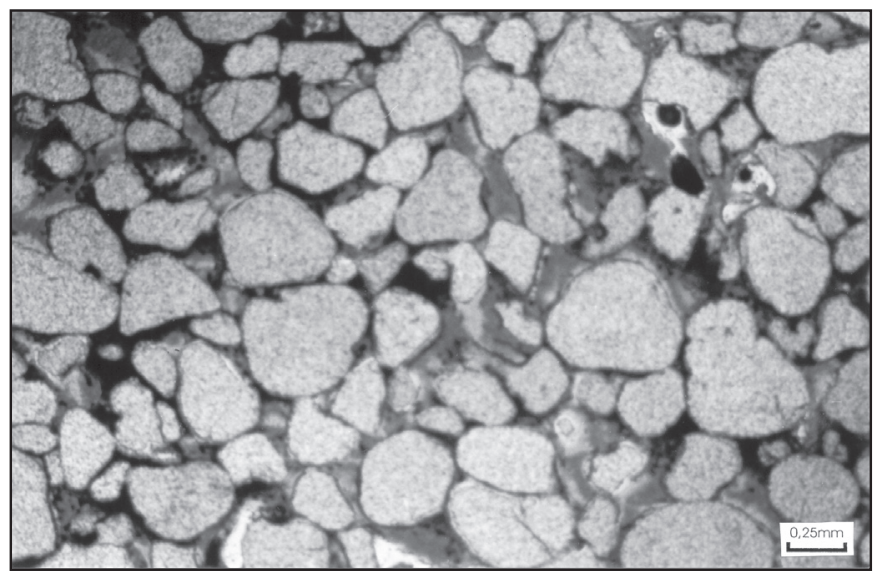

Figura 12. Quartzarenito médio maturo, com grãos de quartzo subarredondados a bem-arredondados, parcialmente corroídos (Nicóis paralelos).

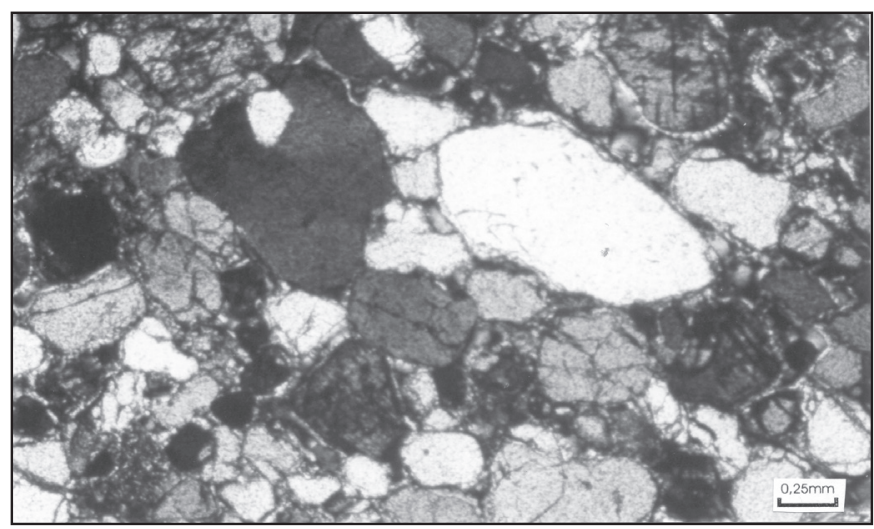

Figura 13. Subarcóseo médio a grosso submaturo, com grãos subangulares a arredondados de quartzo e feldspato; os feldspatos estão parcialmente alterados (Nicóis cruzados).

bóia indicam que, durante seu transporte e deposição, a prolongada fase de quiescência tectônica foi interrompida.

A maior granulometria das areias fluviais e eólicas, bem como a presença marcante de fácies conglomeráticas nesses arenitos, denotam não somente proximidade da fonte. Processos tectônicos atuantes na elevação da área-fonte podem explicar a mudança no calibre do suprimento detrítico à bacia, que influenciou a deposição eólica bacinal (extra-leque aluvial), bem como mudanças no conteúdo mineralógico desse suprimento.

A composição essencialmente quartzosa desses arenitos, com ausência de feldspatos em grande parte das amostras, denota mudanças substanciais na área fonte supridora desses sedimentos, com relação à fonte dos subarcóseos do restante da Formação Pirambóia (Caetano-Chang, 1997).

Embora a maior abundância de feldspatos seja componente esperado em suprimentos de áreas tectonicamente ativas, cabe lembrar que os depósitos de leques aluviais podem ter suas áreas de suprimento bastante restritas, haja vista a compartimentação do sistema via canais alimentadores que abastecem o leque. Nesse sentido, a situação aqui encontrada pode ser peculiar à área amostrada, cuja dominância de quartzarenitos denota áreafonte de constituição essencialmente quartzosa. Neste caso, a alteração de grãos de feldspato a argilo-minerais é pouco provável, haja vista que as argilas da matriz desses arenitos são essencialmente oriundas de infiltração mecânica.

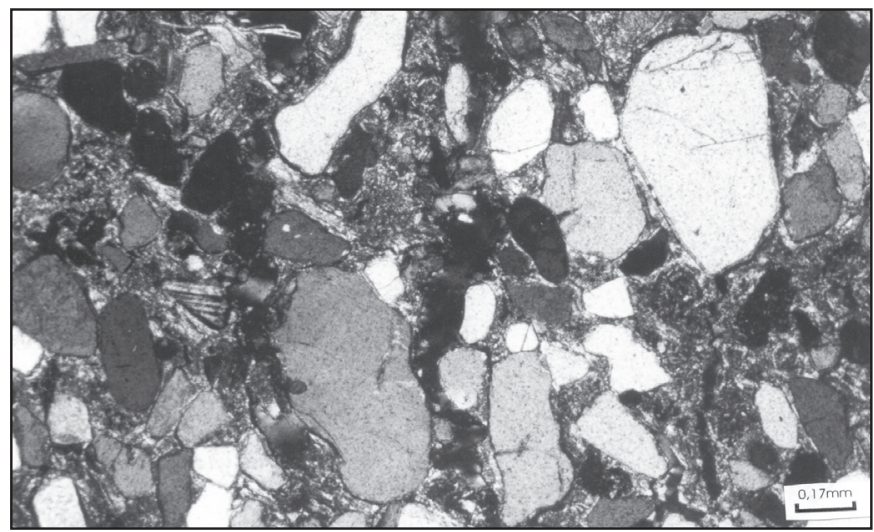

Figura 14. Litarenito feldspático médio a grosso, imaturo. Os grãos de quartzo são angulares a arredondados; os fragmentos de rocha são constituídos principalmente por filitos (Nicóis cruzados).

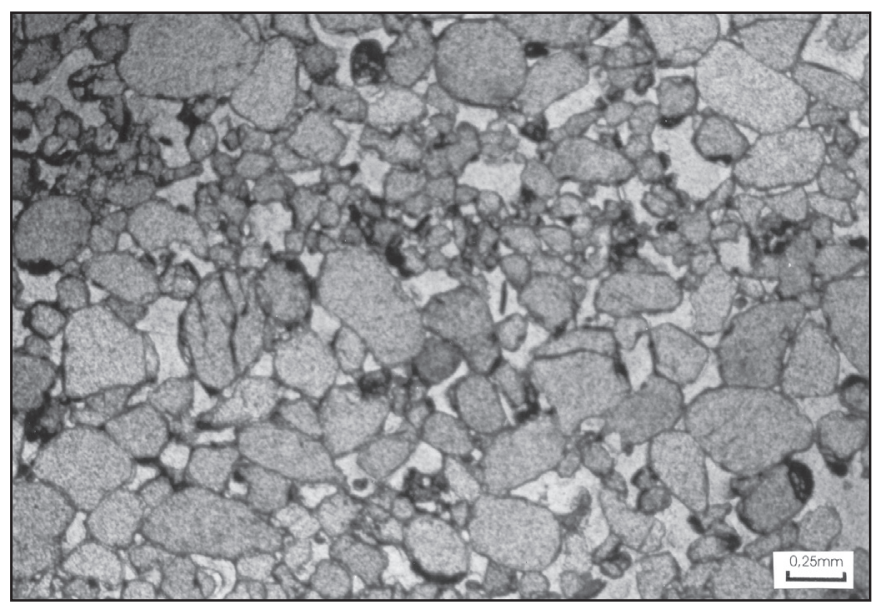

Figura 15. Quartzarenito exibindo lâminas de areias médias a grossas, intercalando lâmina de areias muito finas a finas ( $\mathrm{Ni}$ cóis paralelos).

Desta sorte, os Arenitos Itirapina constituem um pacote rochoso diferenciado do restante da unidade Pirambóia e sua ocorrência é reconhecida como extensiva a toda borda leste da unidade no Estado de São Paulo.

Seus limites de topo e base são bem definidos no campo, particularmente nas áreas de Itirapina e Descalvado. Nesta última, é evidente o contato erosivo, marcado por superfície localmente plana que sobrepõe a sucessão areno-conglomerática, dominantemente fluvial, aos arenitos finos eólicos, típicos da Formação Pirambóia. Já na região de Itirapina, onde é possível acompanhar-se esse mesmo contato basal em áreas mais extensas, é possível verificar-se a relação de interdigitação lateral desses arenitos conglomeráticos com os arenitos eólicos finos da porção superior da formação.

Neste contexto, esses depósitos constituem uma entidade individualizada, com limites de topo e base e posição estratigráfica bem definidos, restritos à borda leste da bacia, cujas características petrológicas (mineralógicas e sedimentológicas), faciológicas e genéticas diferem sobremaneira do restante da Formação Pirambóia. Neste sentido, podem ser definidos como uma unidade estratigráfica distinta; porém, suas relações genético-estratigráficas com a Formação Pirambóia colocam-na como subordinada a esta unidade. 
O contato entre as formações Pirambóia e Botucatu tem sido, na última década, considerado como uma inconformidade regional, delimitando seqüências sedimentares distintas (Zalán et al. 1990, Milani 1992, Caetano-Chang \& Wu 1993). Para Caetano-Chang \& Wu (1993) e Caetano-Chang (1997), o limite entre estas unidades deve ser colocado logo acima dos arenitos conglomeráticos do topo da Formação Pirambóia.

CONSIDERAÇÕES FINAIS Os Arenitos Conglomeráticos Itirapina, informalmente definidos por Caetano-Chang (1997), são aqui formalmente denominados Arenitos Itirapina.

A utilização desta designação: (a) visa melhor identificá-los dentro da Formação Pirambóia, ao mesmo tempo que distinguilos dos arenitos finos eólicos dominantes no restante da unidade; (b) preserva a denominação geográfica já utilizada por CaetanoChang (1997); (c) faz referência à área geográfica onde foram primeiramente descritos por Bósio (1973) e Soares (1973) e onde encontram-se as maiores espessuras aflorantes desses arenitos na região centro-leste paulista.
Estes depósitos - intrincada associação de fácies fluviais de canais entrelaçados e de fácies eólicas - fazem parte do midfan de um sistema de leques aluviais marginais, continuamente retrabalhados pelo vento e condicionados por atividade tectônica que antecedeu às primeiras manifestações do vulcanismo básico na bacia.

Esta cunha clástica, embora restrita às proximidades da borda da bacia, interfere no contexto geral da sedimentação deste intervalo de topo da Formação Pirambóia, expandindo lateralmente a área de interação flúvio-eólica e modificando o suprimento clástico para o interior da bacia, na área dos grandes campos de dunas descritos por Caetano-Chang (1997). Nesta situação, os arenitos geralmente finos e muito finos da unidade competem, neste intervalo superior, com arenitos médios e grossos de dunas eólicas, contemporâneas à deposição flúvio-eólica dos Arenitos Itirapina.

Agradecimentos Os autores agradecem à FUNDUNESP pelo suporte financeiro para realização da pesquisa.

\section{Referências}

Assine M.L. \& Soares P.C. 1995. Interação flúvio-eólica na Formação Pirambóia. In: SBG, Simp. Geol. Sudeste,4, Águas de São Pedro, Boletim Resumos, p. 65.

Bósio, N.J. 1973. Geologia da área de São Pedro, SP. Tese de Doutoramento, Fac. Filos. Ciências e Letras de Rio Claro, Rio Claro-SP, $125 \mathrm{p}$.

Caetano-Chang M.R. 1997. A Formação Pirambóia no centro-leste do Estado de S Paulo. Tese de Livre Docência, Instituto de Geociências e Ciências Exatas, UNESP, Rio Claro-SP, 196 pp.

Caetano-Chang M.R. \& Wu F.T. 1992. Bacia do Paraná: Formações Pirambóia e Botucatu. In: SBG, Congr. Bras. Geol., 37, São Paulo, Roteiro de Excursão 2, p. 1-19.

Caetano-Chang M.R. \& Wu F.T. 1993. A composição faciológica das formações Pirambóia e Botucatu no centro-leste paulista e a delimitação do contato entre as unidades. In: Simp. Cronoestratigrafia da Bacia do Paraná, 1, Rio Claro-SP, Boletim Resumos, p. 93.

Caetano-Chang M.R \& Wu F.T. 1995. As Formações Pirambóia e Botucatu no Estado de São Paulo. In: SBG, Simp. Geol. Sudeste, 4, Águas de São Pedro, Boletim Resumos, p. 64.

Cesero P., Mauro L.M., De Ros L.F. 1989. Técnicas de preparação de lâminas petrográficas e de moldes de poros na PETROBRÁS. Bol. Geociências PETROBRÁS, 3:105-116.

Folk R.L. 1974. Petrology of Sedimentary Rocks. Hemphill Pub. Company, $182 \mathrm{pp}$.

Hubert J.F. 1962. A zircon-tourmaline-rutile maturity index and the interdependence of the composition of heavy mineral assemblages with the gross composition and texture of sandstones. Jour. Sed.
Petrology, 32 : 440-450.

Langford R.P. 1989. Fluvial-aeolian interactions. Part I, Modern System. Sedimentology, 36:1023-1035.

Langford R.P. \& Chan M.A. 1989. Fluvial-aeolian interactions. Part II, Ancient System. Sedimentology, 36:1037-1051.

Milani E.J. 1992. Intraplate tectonics and evolution of the Paraná Basin, SE Brazil. In: M. de Wit \& I.D. Ransome (eds.) Inversion Tectonics of the Cape Fold Belt, Karoo and Cretaceous Basin of Southern Africa. Balkema, Amsterdam, p.: 101-108.

Riccomini C., Gimenez F A., Almeida F.F.M. 1984. Considerações sobre a estratigrafia do Permo-Triássico na região da Serra do Cadeado, Paraná. In: SBG, Congr. Bras. Geol., 33, Rio de Janeiro, Atas, p. 754-764.

Soares P.C. 1973. O Mesozoico Ganduânico no Estado de São Paulo. Tese de Doutorado. F.F.C.L., Rio Claro-SP, 153 pp.

Soares P.C. 1975. Divisão estratigráfica do Mesozóico do Estado de São Paulo. Rev. Bras. Geociências, 5:229-251.

Wu F.T. 1981. Minerais pesados das seqüencias arenosas paleozóica e mesozóica no centro-leste do Estado de São Paulo. Dissertação de Mestrado, Instituto de Geociências, USP, São Paulo, 78p.

Zalan P.V., Wolff S., Conceição J.C.J., Astolfi M.A.M., Vieira I.S., Appi V.T., Zanatto D.A. 1987. Tectônica e sedimentação da Bacia do Paraná. In: SBG, Simp. Sul-Bras. Geol., 3, Atas, Curitiba, p. 441-477.

Manuscrito A-1613

Revisão aceita em 3 de agosto de 2006 